UTILITY: Jurnal IImiah Pendidikan dan Ekonomi

Volume 3, No. 2, Agustus 2019: Page 85-94

ISSN 2549-1377 (Print) || ISSN 2549-1385 (Online)

Available online at http://journal.stkipnurulhuda.ac.id/index.php/utility

\title{
INTERNALISASI NILAI-NILAI PANCASILA MELALUI PENDIDIKAN EKONOMI
}

\author{
Miftakhur Rohmah ${ }^{1}$ \\ ${ }^{1,}$ Stkip Nurul Huda OKU Timur \\ *E-mail: hajjahmiftahu15@gmail.com
}

\begin{abstract}
Abstrak: Pendidikan di Indonesia tidak terlepas dari ajaran Pancasila, nilai-nilainya dapat diinternalisasikan kedalam pendidikan ekonomi.Ekonomi Pancasila yang berorientasi pada sila I yakni ekonomi harus mendasarkan diri pada moralitas, karena Tuhanlah sesungguhnya pemilik dan penguasa atas semuanya, sila ke-II ekonomi itu harus bersifat manusiawi dan adil serta, sila ke-III adalah bentuk nasionalisme ekonomi bahwa setiap kebijakan harus sejalan dengan napas nasionalisme, sila ke-IV merupakan bentuk prinsip demokrasi ekonomi, dan sila ke-V yakni mencapai keadilan bersama untuk menuju kemamuran bangsa Indonesia. Karakter yang dibentuk dalam pendidikan ekonomi Pancasila yakni peserta didik yang memiliki karakter, pola pikir, pola sikap, dan pola perilaku yang sesuai dengan norma dan nilai-nilai Pancasila dalam berekonomi. Metode penelitian yang digunakan adalah metode studi pustaka atau biasa disebut dengan penelitian Liberary Research.
\end{abstract}

Kata Kunci: Nilai-nilai Pancasila, Pendidikan Ekonomi.

\section{PENDAHULUAN}

Pancasila memiliki nilai-nilai luhur bagi kehidupan bangsa yaitu: Ketuhanan, Kemanusiaan, Persatuan, Kerakyatan, dan Keadilan. Nilai tersebut adalah satu kesatuan yang utuh dan mengacu pada satu tujuan. Sebagai suatu ideologi bangsa dan Negara Indonesia maka Pancasila bersumber pada nilai-nilai adat-istiadat, nilainilai kebudayaan bangsa Indonesia serta nilai religius yang terdapat dalam falsafah hidup masyarakat Indonesia. Pendidikan di Indonesia tidak terlepas dari ajaran Pancasila, yakni mengembangkan potensi peserta didik agar menjadi manusia yang beriman dan bertakwa kepada Tuhan Yang Maha Esa, berakhlak mulia, sehat, berilmu, cakap, kreatif, mandiri, dan menjadi warga negara yang demokratis serta bertanggung jawab.

Berkaitan dengan Pendidikan tercantum pada pasal 31 dan pasal 32 terkait tentang kebudayaan. Pasal 31 dan pasal 32 berada pada 1 bab yang sama di dalam Undang-Undang Dasar, karena pendidikan dan kebudayaan memiliki keterkaitan satu sama lain yakni saling mendukung dalam meningkatkan kemajuan kualitas pendidikan dan kebudayaan. Pada pasal 31 ayat 1 mengemukakan bahwasanya setiap warga negara berhak mendapatkan pendidikan. Kemudian Pasal 32 ayat 1 menjelaskan bahwasanya negara mamajukan kebudayaan nasional Indonesia 
ditengah peradaban dunia dengan manjamin kebebasan masyarakat dalam memelihara dan mengembangkan nilai-nilai budayanya. Sehingga nilai-nilai budaya bangsa yang bersumber dari Pancasila dan UUD 1945 dapat diintegrasikan dan diwujudkan dalam pembelajaran merupakan paradigma dalam dunia pendidikan nasional Inovasi yang dilakukan dalam pebelajaran tersebut merupakan perwujudan dari demokratisasi dan disentralisasi pendidikan yang ada (Rahmah: 2016). Pendidikan yang ada disekolah-sekolah diharuskan mengadopsi sistem pembelajaran yang bermuatan Pancasila dan UUD 1945, dimana rancangan, proses, dan evaluasi pembelajaranya berorentasi pada Pancasila dan UUD 1945.

Keharusan pelaksanaan pendidikan yang berpedoman kepada kebudayaan dan nilai-nilai yang berdasarkan Pancasila dan UUD 1945 telah tercantum jelas di dalam UUD 1945. Landasan yuridis yang sesuai dengan hal tersebut adalah UndangUndang RI Nomor 20 tahun 2003 tentang sistem pendidikan Nasional, yakni pasal 1 ayat 2 yang berbunyi:

"Pendidikan nasional adalah pendidikan yang berdasarkan

Pancasila dan Undang-Undang Dasar Negara Republik Indonesia Tahun 1945 yang berakar pada nilai-nilai agama, kebudayaan nasional Indonesia dan tanggap terhadap tuntutan perubahan zaman". Kemudian pada pasal 2 juga disebutkan bahwa "Pendidikan Nasional berdasarkan Pancasila dan UUD 1945".

Pancasila Merupakan Bentuk ideologi bangsa yang dapat dijadikan dasar bagi pendidikan Ekonomi di Indonesia. Ekonomi Pancasila yang muncul merupakan jawaban atas pertanyaan terkait pertumbuhan ekonomi, persamaan dan keadilan ekonomi. Pelaksanaan pendidikan ekonomi Pancasila tercantum jelas di dalam UUD 1945 pada pasal 36 ayat 3 butir J yakni:

"Kurikulum disusun sesuai dengan memperhatikan kultur bangsa Indonesia yang berupa persatuan nasional dan nilainilai kebangsaan. Sehingga jelas bahwasanya pendidikan yang dilaksanakan di Indonesia harus berpedoman kepada kebudayaan dan nilai-nilai yang berdasarkan Pancasila dan UUD 1945."

Dari uraian di atas dapat ditarik kesimpulan bahwasanya Pendidikan yang terlaksana harus sesuai dengan Pancasila dan UUD 1945 sesuai dengan amanat konstitusi nasional bangsa Indonesia. Pendidikan yang ada harus mengadopsi khasanah budaya bangsa sehingga pendidikan khususnya pendidikan ekonom dapat mengiternalisasikan nila-nilai yang terkandung pada Pancasila dan sejalur dengan konsep demokrasi ekonomi.

\section{METODE}

Metode penelitian yang digunakan adalah metode studi pustaka. Penelitian ini 


\section{INTERNALISASI NILAI-NILAI PANCASILA MELALUI PENDIDIKAN EKONOMI}

bertujuan untuk mendeskripikan atau memaparkan bagaimana ekonomi kerakyatan sebagai landasan pendidikan ekonomi seacara kualitatif. Jenis penelitian kualitatif ini memaparkan kejadian yang nyata terjadi dalam konteks sehari-hari tanpa dimanipulasi. Dalam pengumpulan data dilakukan dengan cara melakukan studi kepustakaan (Liberary Research). Studi kepustakaan dilakukan dengan cara membaca serta mempelajari berbagai jurnal ilmiah, buku, website serta sumber baca lainya demi memperoleh kerangka teori yang dapat menjadi landasan penelitian.

Penelitian pustaka atau library research menurut Sudrajat (2005:7) merupakan "Studi kepustakaan adalah penelitian dengan teknik pengumpulan data melalui mengadakan studi penelaahan terhadap buku-buku, literatur-literatur, catatancatatan, dan laporan-laporan yang ada hubungannya dengan masalah yang dipecahkan". Sukmadinata (2015:74) juga mengemukakan, "Penelitian pustaka atau library research yakni penelitian yang dilakukan dengan teknik menghimpun informasi yang relevan dengan topik atau masalah yang akan atau sedang diteliti". Metode penelitian pustaka atau library research dilakukan dengan menggunakan teknik content analysis. Menurut Sukardi (2012:21) menjelaskan, "Content Analysis merupakan penelitian yang bersifat pembahasan yang mendalam tentang isi suatu informasi tertulis atau tercetak dalam media massa". Pengertian tersebut diatas jelas bahwasanya Content Analysis adalah metode yang meliputi seluruh analisis menganai isi teks, namun disisi lain Content Analysis juga digunakan untuk mendeskripsikan pendekatan analisis khusus. Content Analysis yaitu suatu cara agar dapat mengambil kesimpulan dengan mengident ifikasi berbagai karakteristik khusus suatu pesan secara objektif, sistematis, dan generalis.

\section{HASIL DAN PEMBAHASAN}

\section{Hasil}

Pelaksanaan pendidikan yang ada di Indonesia masih menunjukan banyak pendidikan baik pendidikan ditingkat dasar maupun pendidikan diperguruan tinggi pembelajaranya masih mengadopsi pembelajaran dengan teori-teori barat. Hal tersebut jelas tidak sesuai dengan kondisi bangsa Indonesia, seperti pada pembelajaran ekonomi yang mengadopsi teori-teori barat. Ketika teori ekonomi umum diterapkan di Indonesia maka banyak yang tidak sesuai. Faktor ketidak sesuaian tersebut berasal dari kondisi riil masyarakat Indonesia, sehingga perlu adanya penyesuaian dengan teori ekonomi yang baru melalui penelitian-penelitian. Menurut Mubyarto (2009 : 215) pendidikan ekonomi yang berbasis ekonomi konvensial (barat), ilmu ekonomi ini tidak mampu mendobrak ketimpangan (keadilan), kemiskinan terstruktur, kerusakan alam (lingkungan), meluasnya degradasi moral dan meregangnya koherensi sosial.

Pendidikan ekonomi yang teruarai seperti tersebut di atas hanya dapat melihat faktor-faktor luar ekonomi ekonomi (politik, sosial, budaya) dan fakta-fakta politik 
ideologi dan mengabaikan nalar teorotik, keilmuan yang sangat berpengaruh. Pelaksanaan pendidikan ekonomi yang keliru dengan mengadopsi teori-teori barat ini sudah mendominasi pembelajaran ekonomi Indonesia. Sehingga pembelajaran ekonomi di Indonesia mengarah pada ajaran ekonomi kapitalis/ekonomi pasar. Menurut Sri-Edi Swasono (2005:5) bahaya pembelajaran ekonomi Barat adalah pada buku teks yang mainstream economics dan literatur ilmu ekonomi yang pro Neoklasik.

Pembelajaran ekonomi- ekonomi barat mengajarkan manusia untuk individualisme atau mengutamakan diri sendiri (self-interes), pamrih dan serakah serta nantinya akan melahirkan kondisi perekonomian yang kapitalis/liberal. Sehingga Pendekatan ekonomi Indonesia juga berbeda, hal tersebut berdasarkan penelitian yang dikutip dari Rahmah (2017) pada penelitian Julius Herman Boeke pada tesisnya tahun 1882-1956 yang berjudul Dual economies yang kemudian memunculkan teori baru bagi ilmu ekonomi Indonesia. Kemudian dalam disertasinya pada tahun 1910 yang berjudul Tropisch-Koloniale Staathuishoudkunde: Het Problem (Masalah Perekonomian Kolonial Tropik) dari sudut ekonomi Boeke mengemukakan dalam perekonomian di Indonesia yang berbeda perlu adanya pendekatan ekonomi yang berbeda, teori ekonomi umum tidak berlaku bagi sistem sosial yang bersifat khas, sehingga perlu adanya teori baru yang berbeda dengan teori-teori umum. Indonesia memiliki pendekatan ekonomi yang disebut dengan istilah ekonomi Pancasila, yaitu sistem ekonomi ekonomi yang disusun berdasarkan Pancasila dan pasal 33 UUD 1945 dan dilengkapi oleh pasal 23, 27 ayat 2, 34, serta penjelasan pasal 2 UUD 1945.

Pelaksanaan pendidikan ekonomi yang keliru dengan mengadopsi teori-teori barat ini sudah mendominasi pembelajaran ekonomi Indonesia. Sehingga pembelajaran ekonomi di Indonesia mengarah pada ajaran ekonomi kapitalis/ekonomi pasar. Menurut Sri-Edi Swasono (2005:5) bahaya pembelajaran ekonomi Barat adalah pada buku teks yang mainstream economics dan literatur ilmu ekonomi yang pro Neo-klasik. Pembelajaran ekonomi- ekonomi barat mengajarkan manusia untuk individualisme atau mengutamakan diri sendiri (self-interes), pamrih dan serakah serta nantinya akan melahirkan kondisi perekonomian yang kapitalis/liberal.

Kesalahan pembelajaran ekonomi yang telah terjadi selama ini baik disekolah tingkat dasar maupun perguruan tinggi masih mempelajari ekonomi-ekonomi barat (Neo-liberalisme). Hal ini dikarenakan belum adanya literasi khusus yang menggali tentang ekonomi dalam perspektif Pancasila dan UUD 1945. Oleh karena itu, tuntutan untuk berinovasi dan melahirkan ide-ide baru dalam pendidikan ekonomi merupakan tanggung jawab seluruh warga negara Indonesia umumnya dan khusnya bagi para pendidik maupun calon pendidik. Tanggung jawab untuk membentuk pola pikir yang baru (normatif ideologis) agar anak didik benar-benar memahami ilmu ekonomi sebagai ilmu yang bermoral (a moral science). Hal ini dapat diawali dengan pendidikan yang menginternalisasikan nilai-nilai Pancasila kedalam pembelajaran. 


\section{INTERNALISASI NILAI-NILAI PANCASILA MELALUI PENDIDIKAN EKONOMI}

Kesempatan untuk merubah mainstream ekonomi melalui pendidikan yang dirintis melalui pembelajaran dikelas, merupakan kesempatan emas untuk anak-anak muda mengubah pola pemikiran mainstream ekonomi dan memperjuangkan kembali ekonomi Pancasila.

Sudah menjadi keharusan jika pelaksanaan pendidikan kita dirubah menjadi pendidikan yang berciri khaskan Indonesia sesuai dengan kultur budaya bangsa Indonesia. Karena ideologi Pancasila seharusnya dianut dan diwujudkan dalam pendidikan sehingga dapat mewujudkan masyarakat yang bermoral dan berkarakter Pancasila. Dengan demikian melalui pendidikan ekonomi Pancasila baik didalam proses pembelajaran disekolah (formal), luar sekolah dan keluarga (non formal) akan menciptakan Sumber Daya Manusia Indonesia yang bersikap, berprilaku, dan berkarakter Pancasila. Pendidikan Pancasila merupakan upaya dalam membangun ilmu pengetahuan yang peka terhadap permasalahan dan isu-isu terkait ketuhanan (yang berhubungan dengan Agama, etika dan moral), kemanusiaan, kebangsaan (nasionalisme dan patriotisme) dan kerakyatan serta keadilan. Fokus pada pelaksanaan pembelajaran ekonomi Pancasila yakni pada sistem kehidupan ekonomi yang berlandaskan ideologi Pancasila yang menjadi jati diri bangsa Indonesia untuk menuju masyarakat yang berkeadilan dan mewujudkan kesejahteraan bagi rakyat Indonesia.

Kekeliruan lain juga dapat dilihat dari pembelajaran ekonomi yang lebih mengarah kepada ekonomi Neoliberal sehingga pembelajaran ekonomi yang selama ini diajarkan belum sepenuhnya dikaitkan dengan ekonomi Pancasila. Sehingga dalam prakteknya dampak pembelajaran ekonomi barat mengakibatkan siswa bersifat individual dan kurangnya rasa kebersamaan dan kekeluargaan. Kesalahan inilah yang seharusnya kita sadari dan sudah saatnya pula untuk diluruskan, sebab jika kita biarkan maka keberlangsunganya akan terus menerus yang berdampak negatif bagi masa depan bangsa Indonesia.

Disiplin ilmu pembelajaran ekonomi merupakan penanaman modal insani, karena pembelajaran ekonomi adalah bidang studi yang berkaitan langsung dengan kehidupan sehari-hari. Berdasarkan pada orientasi yang dihasilkan dari Pancasila dan pasal 33 UUD 1945 tersebut, maka seyogyanya perekonomian yang ada di Indonesia perlu diwujudkan dalam konteks pembelajaran ekonomi. Nilai-nilai yang terkandung didalamnya merupakan ciri khas dan jati diri bangsa yang mampu dijadikan teladan dalam pembelajaran ekonomi Indonesia, terutama pada lembaga pendidikan formal. Sehingga dapat terbentuknya peserta didik yang memiliki karakter, pola pikir, pola sikap, dan pola perilaku yang sesuai dengan norma dan nilai-nilai Pancasila. Oleh karena itu, tuntutan untuk berinovasi dan melahirkan ideide baru dalam pendidikan ekonomi merupakan tanggung jawab seluruh warga negara Indonesia umumnya dan khusnya bagi para pendidik maupun calon pendidik. Tanggung jawab untuk membentuk pola pikir yang baru (normatif ideologis) agar anak didik benar-benar memahami ilmu ekonomi sebagai ilmu yang bermoral (a moral science). Hal ini dapat diawali dengan pendidikan yang menginternalisasikan 
nilai-nilai Pancasila kedalam pembelajaran. Kesempatan untuk merubah mainstream ekonomi melalui pendidikan yang dirintis melalui pembelajaran dikelas, merupakan kesempatan emas untuk anak-anak muda mengubah pola pemikiran mainstream ekonomi dan memperjuangkan kembali ekonomi Pancasila.

Menurut Mubyarto (2003) nilai-nilai Pancasila dalam berekonomi dirumuskan sebagai berikut:

- Pancasila adalah ekonomi yang berorientasi pada sila I ekonomi harus mendasarkan diri pada moral, karena Tuhanlah sesungguhnya pemilik dan penguasa atas semuanya,

- Sila ke-II ekonomi itu harus bersifat manusiawi dan adil serta,

- Sila ke-III adalah bentuk nasionalisme ekonomi bahwa setiap kebijakan harus sejalan dengan napas nasionalisme,

- Sila ke-IV merupakan bentuk prinsip demokrasi ekonomi, dan

- Sila ke-V sudah jelas bahwa tujuanya adalah mewujudkan keadilan sosial bagi seluruh rakyat Indonesia dan UUD 1945 pasal 33 sebagai landasanya dan ayat 1 pada pasal 33 lebih memperkuat orientasi pelaksanaanya. Sehingga dapat tercapainya tata, titi, tentrem, kerta rahardja, benar-benar mencapai keaadilan dan kemakmuran.

Berdasarkan Uraian tersebut maka dapat ditarik kesimpulan bahwasanya ideologi Pancasila seharusnya dianut dan diwujudkan dalam pendidikan sehingga dapat mewujudkan masyarakat yang bermoral dan berkarakter Pancasila. Dengan demikian melalui pendidikan ekonomi Pancasila baik didalam proses pembelajaran disekolah (formal), luar sekolah dan keluarga (non formal) akan menciptakan Sumber Daya Manusia Indonesia yang bersikap, berprilaku, dan berkarakter Pancasila. Pendidikan Pancasila merupakan upaya dalam membangun ilmu pengetahuan yang peka terhadap permasalahan dan isu-isu terkait ketuhanan (yang berhubungan dengan Agama, etika dan moral), kemanusiaan, kebangsaan (nasionalisme dan patriotisme) dan kerakyatan serta keadilan. Fokus pada pelaksanaan pembelajaran ekonomi Pancasila yakni pada sistem kehidupan ekonomi yang berlandaskan ideologi Pancasila yang menjadi jati diri bangsa Indonesia untuk menuju masyarakat yang berkeadilan dan mewujudkan kesejahteraan bagi rakyat Indonesia.

\section{Pembahasan}

Pembelajaran ekonomi yang terjadi dapat mempengaruhi pola berpikir dan pola sikap siswa yang berpijak pada keyakinan bahwa manusia merupakan homo economicus. Sehingga dalam hal ini mengajarkan siswa selalu mengejar self inters secara efesien. Efesiensi ekonomi dianggap hanya dapat terwujud melalui persaingan ala pasar bebas, akibatnya ajaran ini menonjolkan persaingan (kompetitivisme), dan bukan kerjasama (cooperative), dan bukan kebersamaan (mutualism), juga bukan pula kekeluargaan (brotherhood), serta juga bukan kepentingan dan kemakmuran bersama (mutual inters). Kecenderungan ajaran 


\section{INTERNALISASI NILAI-NILAI PANCASILA MELALUI PENDIDIKAN EKONOMI}

ekonomi neoklasik yang mengutamakan pasar melupakan aspek kelembagaan ekonomi, sosial-budaya, keberlanjutan lingkungan hidup, dan prinsip-prinsip yang dianut oleh bangsa Indonesia yakni gotong royong.

Ekononomi Pancasila merupakan suatu orientasi yang dapat dikembangkan menjadi suatu sistem untuk mencapai suatu tujuan filsafati, pandangan filsafati di bidang kehidupan ekonomi sebagai implikasi langsung dari diterimanya Pancasila di negeri ini. (Edi-Swasono, 1981:1) Lebih lanjut dijelaskan bahwa ekonomi Pancasila yakni ekonomi yang mengarah ke sosialistis dan tidak ada hubunganya dengan marxisme dengan landasan dialektika/materialisme, tetapi ekonomi Pancasila yang sosialistis ini merupakan etika agama, suatu tumbuhan yang berakar pada adatistiadat Indonesia (kolektivisme) dan tuntutan perjuangan bangsa. Sedang menurut Poespapawardojo (1981:122) ekonomi Pancasila adalah ekonomi yang mengungkap secara jelas suasana kemanusiaan dalam rumusan yang tertulis dalam penjelasan tentang UUD 1945 dan selanjutnya visi dasar yang terkandung Pancasila yakni menciptakan kehidupan kenegaraan dan kemasyarakatan, khususnya kehidupan ekonomi yang mencapai keadilan sosial bagi seluruh rakyat Indonesia.

Lebih lanjut dijelaskan oleh Moh Hatta (dalam Edi-Swasono, 1981:5) tentang ekonomi Pancasila yaitu ekonomi yang mengarah pada sosialisme yakni ekonomi sosialis Indonesia, yang kemudian orientasinya Kepada: Ketuhanan Yang Maha Esa (yakni adanya etik \& moral agama, bukan matreliasme); Kemanusian yang adil dan beradab (artinya tidak adanya pemerasan/eksploitasi manusia); persatuan (artinya Kekeluargaan, kebersamaan, nasionalisme dan patriotisme ekonomi); kerakyatan (artinya mengutamakan ekonomi rakyat dan hajat hidup orang banyak); serta keadilan sosial (artinya adanya persamaan, kemakmuran masyarakat yang paling utama, bukan kemakmuran orang-seorangan. sejalan dengan pendapat diatas menurut Mubiyarto (dalam Dumairy \& Tali Nugroho, 2014:21) dikutip sebagai berikut:

"Pada dasarnya penafsiran Sistem Ekonomi Pancasila (SEP) sebagai sistem ekonomi yang berorientasi pada sila I ekonomi harus mendasarkan diri pada moral, karena Tuhanlah sesungguhnya pemilik dan penguasa atas semuanya, sila ke-Il ekonomi itu harus bersifat manusiawi dan adil serta, sila ke-III adalah bentuk nasionalisme ekonomi bahwa setiap kebijakan harus sejalan dengan napas nasionalisme, sila ke-IV merupakan bentuk prinsip demokrasi ekonomi, dan sila ke-V sudah jelas bahwa tujuanya adalah mewujudkan keadilan sosial bagi seluruh rakyat Indonesia dan UUD 1945 pasal 33 ayat 1 lebih memperkuat orientasi pelaksanaanya. Sehingga dapat tercapainya tata, titi, tentrem, kerta rahardja, benar-benar adil dan makmur".

Menurut Rahmah (2017: 38-39) menyatakan bahwa : Pancasila selain sebagai ideologi bangsa juga merupakan kristalisasi dari nilai-nilai yang telah berakar dalam khasanah budaya bangsa, secara rinci nilai-nilai tersebut tertuang dalam pembukaan UUD 1945 dan bentuk kongkret dari pengamalan Pancasila dan UUD 1945 adalah 
GBHN. Pancasila dan UUD 1945 adalah landasan konstitusional yang digunakan dalam sistem ekonomi Indonesia.

Dalam pasal 33 UUD 1945 tersebut tercantum dasar demokrasi ekonomi produksi dikerjakan oleh semua, untuk semua di bawah pimpinan atau pemilikan anggota-anggota masyarakat. Kemakmuran masyarakat yang diutamakan, bukan orang-seorang. Sebab itu perekonomian disusun sebagai usaha bersama atas azas kekeluargaan. Penjelasan makna pasal 33 ayat 1 oleh Sri Edi Suwarsono (dalam Witjaksono, 2013:2) dikutip sebagai berikut:

"Perekonomian" tentu meliputi seluruh wadah ekonomi, tidak saja badan usaha koperasi, tetapi juga meliputi BUMN dan juga badan usaha swasta. Disusun (dalam konteks orde ekonomi dan sistem ekonomi) artinya adalah bahwa perekonomian, tidak bisa disusun sendiri melalui mekanisme pasar secara impretif tidak boleh dibiarkan mengikuti kehendak dan selera pasar. Dengan demikian peranan negara tidak hanya mengintervensi, tatapi menata, mendesain, merekonstruksi, untuk mewujudkan kebersamaan dan asas kekeluargaan serta terjaminya keadilan sosial bagi seluruh rakyat indonesia."Usaha besama" adalah wujud paham mutualisme, suatu kehendak untuk senantiasa mengutamakan semangat kerjasama dalam kegtotong royongan, dalam kejamaah-an. Dengan mengutamakan keserikatan dan tidak sendiri-sendiri. "Asas kekeluargaan" brotherhood atau ke-ikhuwah-an (yang bukan kinship neopotistik) sabagai pernyataan adanya tanggung jawab bersama untuk menjamin kepentingan bersama, kemajuan bersama dan kemakmuran bersama, layaknya brotherhood adalah ke-ukhuwah-an yang wathoniyah.

Sedang menurut Jimly (2010) menjelaskan juga arti UUD 1945 pasal 33 ayat 1 yakni sebagai berikut: (i) Disusun, (ii) usaha bersama, (iii) asas kekeluargaan. Dengan menyatakan bahwa perekonomian itu disusun maksutnya bahwa perekonomian merupakan suatu sususnan mulai dari susunan yang bersifat nasional sampai ke susunan yang bersifat nasional sampai ke daerah-daerah provinsi dan kabupaten/kota di seluruh Indonesia. susunan perekonomian itu merupakan suatu usaha bersama atas asas kekeluargaan. Kemudian penafsiran Widjojo Nitisastro mengenai pengertian usaha bersama yang dimaksud tidak lain merupakan usaha bersama seluruh rakyat Indonesia di bidang perekonomian. Dengan demikian, "Perekonomian disusun sebagai usaha bersama" tidak lain merujuk kepada pengertian suatu sistem perekonomian nasional sabagai usaha bersama seluruh elemen rakyat Indonesia. Pengertian kebersamaan itu, tidak hanya berkaitan dengan konsep bentuk usaha, tetapi lebih jauh lagi berkaitan pula dengan konsep pelaku ekonomi yang tidak hanya dijalankan oleh bangunan perusahaan. Artinya di dalam kegiaatan usaha swasta, apakah itu berbentuk Perseorangan Terbatas atau lainya, apakah itu asing, patungan dengan asing, domestik pribumi maupun domestik nonpribumi, harus dihidupkan pula semangat keusaha-bersamaan dan berasaskan 


\section{INTERNALISASI NILAI-NILAI PANCASILA MELALUI PENDIDIKAN EKONOMI}

kekeluargaan.

Asas kekeluargaan dalam pasal 33 ayat 1 juga harus dipahami dalam pengertian yang luas artinya dalam asas kekeluargaan ini bukan lagi hanya dalam pengertian yang organis dalam wujud pelaku ekonomi yang harus dalam bentuk koperasi yang dalam hal ini sebagai badan usaha secara sempit. Kemudian, prinsip kebersamaan dan asas kekeluargaan juga pemaknaanyapun juga jangan sampai disalah artikan menjadi pengertian yang family system yang bernilai negatif.

Berdasarkan paparan di atas tentang pasal 33 ayat 1 , maka peneliti bermaksut akan mengembangkan pembelajaran dengan memasukkan nilai-nilai Pancasila berdasarkan semangat kebersamaan dan kekeluargaan kedalam proses pembelajaran ekonomi di kelas sehingga diharapkan dapat membentuk karakter peserta didik yang saat ini cenderung mengarah kearah liberalisme agar tidak bersifat individualisme menjadi brotherhood, cooperative, dan juga berjiwa nasionalisme serta memiliki jiwa patriotisme yang tinggi.

\section{SIMPULAN}

Sesuai pembahasan di atas, dapat disimpulkan tentang internalisasi pembelajaran ekonomi Pancasila di Indonesia, antaralain: nilai-nilai pada pembelajaran ekonomi Pancasila di Indonesia sudah disisipkan dalam pembelajaran Ekonomidengan tema Demokrasi Ekonomi yang cakupanya masih dikategorikan minim. Kemudian pembelajaran yang disampaikan pada mpembelajaran ekonomi belum menggunakan contoh yang kontekstual sesuai dengan kondisi alam Indonesia. Selanjutnya pembelajaran ekonomi Pancasila belum menjadi mata pelajaran yang dicantumkan pada kurikulum Pendidikan baik ditingkat dasar maupun SMA.

Sehingga perlu adanya kebijakan nasional untuk mendukung pelaksanaan internalisasi nilai-nilai Pancasila kedalam pendidikan ekonomi secara komprehensif substansi formal dari pembalajaran ekonomi Pancasila. Adanya pelatihan-pelatihan terkait topik atau isue yang mengangkat Ekonomi yang berciri khaskan khasanah budaya bangsa.

\section{UCAPAN TERIMAKASIH}

Ucapan terimakasih ditujukan kepada STKIP Nurul HUda Program Studi Pendidikan Ekonomi tempat peneliti meniti karir dan melaksanakan Tri Dharma Perguruan Tinggi Serta Tim Jurnal Utility STKIP Nurul Huda.

\section{REFERENSI}

Rohmah, M. (2016, December). EKONOMI KERAKYATAN SEBAGAI LANDASAN PENDIDIKAN EKONOMI INDONESIA. In National Conference on Economic Education. 
Miftakhur Rohmah ${ }^{1}$

Depdiknas. (2003). Undang-Undang RI Nomor 20. Tahun 2003, Tentang Sistem Pendidikan Nasional. Jakarta: Depdiknas.

Tim Visi Yustisia. (2014). UUD Negara Republik Indonesia 1945: Tentang Kurikulum Pendidikan. Jakarta : Visimedia.

M. Subana, Sudrajat, (2005), Dasar-Dasar Penelitian IImiah, Bandung: Pustaka Setia

Sukmadinata, N.S. (2015). Metode Penelitian Pendidikan. Bandung: Remaja Rosadakarya

Sukardi. (2012). Metode Penelitian Pendidikan. Yogyakarta: Bumi Aksara..

Mubyarto. (1987). Ekonomi Pancasila: Gagasan dan Kemungkinan. Jakarta: LP3ES. . (1988). Sistem dan Moral Ekonomi Indonesia. Jakarta: LP3ES.

Swasono Sri-Edi. (2002). Mengubah Pakem : Kompetensi an Integritas Sarjana Ekonomi. Makalah disajikan pada seminar yang diselenggarakan oleh Bpappenas bekerjasama dengan United Nation Support Facility for Indonesia Recovery (UNSFIR), Jakarta: 24-25 Oktober 2002.

Swasono Sri-Edi. (2016). Pendidikan Demi Ibu Pertiwi. Yogyakarta: UST-PRESS.

ROHMAH, M. (2017). Pengembangan Perangkat Pembelajaran Ekonomi Pancasila. DISERTASI dan TESIS Program Pascasarjana UM.

Asshiddiqiie, Jimly, 2010. Konstitusi dan Konstitusionalisme Indonesia, Jakarta, Sinar Grafika. 